Divisional ski races to be held under the chairmanship of Daniel Chemla at Aussois in the French Alps on 25 - 27 March 1981 on which occasion the championships are entitled "Nonlinear Optics of Excited Solids". Werner Schmidt and myself are in fact not so invincible as you may think as a crucial choice of route at Davos last year depended upon our detecting from the indicator board which runs were open. As both of us are colour-blind it is sheer luck that we are still alive.

Our talents extend beyound skiing. The Secretary, Rene Dändliker, is a highly respectable tennis player, as is the Vicechairman's wife, Frau Christl Kompa. In the first encounter between the Chairman and Secretary held in Zurich, the Secretary won $7-5,6-4$, whereas the Chairman gained his revenge at the molecules meeting in Edinburgh, 6-4, 6-3. A decider is planned in London on 10 July, 1980 (the date of the next Board meeting) to coincide with the end of the Wimbledon Championships.

Unfortunately not all our sporting efforts can be treated so light-heartedly and we were all very distressed by the collapse at the football match held in Novosibirsk in July last year (at which the Chairman broke his foot) of Sergio Porto who had done such fine work on Raman scattering in solids. The Chairman and Secretary will attend the memorial meeting in Rio, 29 June -3 July.

Returning to QED, apart from the progress with the big lasers that is being made at Garching, Rutherford and elsewhere, our subject remains excitingly alive. There is active work in optical bistability, free electron lasers and laser spectroscopy of single atoms although Europe appears to be lacking somewhat in phase conjugation, one of the latest "whizz" words in the USA. We aim in our future programme to provide interesting meetings on topical subjects for anybody in Europe who is prepared to take some initiative and stir us up - in other words, there is more in the QED than just lasers, and we welcome new members and new ideas.

S.D. Smith

1980 EPS

\title{
Hewlett-Packard Europhysics Prize
}

The 1980 Hewlett-Packard Europhysics Prize of the EPS has been awarded to two physicists for their separate contributions towards achieving a quantitative understanding of the physical and chemical behaviour of solid state materials through the development of original methods for the calculation of their electronic properties. The award winners are: Dr. O. Krogh Andersen of the Max-Planck-Institut für Festkörperforschung, Stuttgart; and Dr. Andries R. Miedema of Philips' Research Laboratories, Eindhoven.

They will share the prize of $20000 \mathrm{Sw}$. Fr. equally. The formal presentation will be made during the International Conference on the Physics of Transition Metals in Leeds, 18-22 August.

The prize, which is donated annually by Hewlett-Packard to EPS, is for "outstanding achievement in solid state physics".
Dr. Anderson is honoured for his development of new methods for the numerical calculation of band structures. These have significantly increased the speed of making such calculations, transforming them into a highly efficient procedure and greatly extending the range of materials that can be studied. So effective is his approach, his method, and subsequent developments of it, are now used for elaborating the input data for more complex computations.

Dr. Miedema is honoured for his essentially empirical approach to similar problems, which have had a striking success even though the underlying theoretical justification is not understood. His empirical alloy models allow a number of properties, notably those of a thermo-dynamic nature, to be derived and provide a powerful tool for studying new alloys and tailoring their porperties to engineering requirements.

\section{ACAPPI/CMD Summer School}

A new departure for EPS is the organization of a Summer School on Material Science and Technology (1st Course Applications of Ferroelectrics) which is being held at the Ettore Majorana Centre of Erice, 1-15 July, 1980. While some attention will be paid to the switching dipole properties of ferroelectrics, the principal topics discussed will be the exploitation of such phenomena as piezoelectricity and pyroelectricity, as well as the dielectric and optical properties of ferroelectrics, with particular emphasis on the enhancement effects that occur at or in the neighbourhood of phase transitions.

The Course is aimed at post-graduate students in research institutes and industry.

Inscriptions accompanied by personal details and background will be accepted until early in June by the Course Director, F.W. Ainger,

Plessey Research (Caswell) Ltd.,

Allen Clark Research Centre, Caswell,

Towcester, Northants NN12 8EQ, U.K.

\section{Enlargement of ESO}

At its meeting on 26 March the Council of the European Southern Observatory agreed to Italy and Switzerland becoming Member States of the Organization with effect from early 1981. Parliamentary ratification in the two countries has still to be completed. In anticipation of the material increase in demand for observing time on the big telescopes at La Silla in Chile that will arise, it is proposed to construct a new $3.5 \mathrm{~m}$ telescope, the New Technology Telescope or NNT, that will be of a revolutionary light weight design.

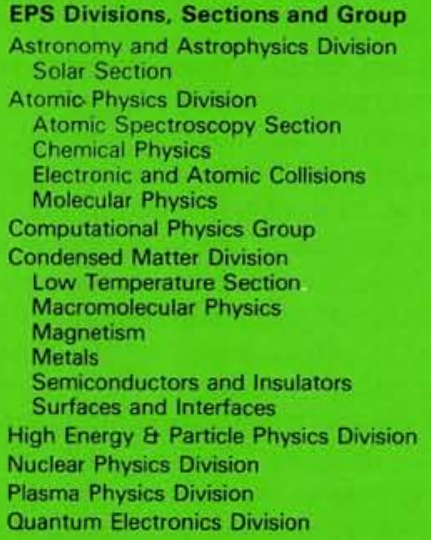

EPS Divisions, Sections and Group

Astronomy and Astrophysics Division

Electronic and Atomic Collisions

Molecular Physics

Temperature Section

Thomolecular Physics

Nuclear Physics Division

Quantum Electronics Division
Europhysics News is the official journal of the European Physical Society that comprises 28 National Societies, Academies and Groups, over 3000 Individual Ordinary Members and 30 Associate Members. Governing bodies of EPS are the General Meeting, Council and an elected Executive Committee responsible for detailed policy EPS promotes the collaboration of physicist throughout Europe and encourages all aspects of international exchange in physics. EPS awards scholarships for research and studies in different countries. EPS publishes, in addition to Europhysics News, Europhysics Conference Abstracts, Europhysics Educa tion News and the Proceedings of its General Contion News and the Proceedings of its General Con
ferences. Individual Ordinary Members receive Europhysics News (subscription for non-members: 75 Sw.Fr./a), substantial rebates on many publications and pay reduced fees at conferences. Application for membership is made through the permanent Secretariat in Geneva. Annual subscription for members of a $\mathrm{Na}$ tional Society from 1 January, 1980 is 32 Sw. Fr.

\section{Editor: E.N. Shaw}

Meetings Compilation: W.S. Newman

Editorial Board:

K. Appert, A. Baratoff, G.J. Béné,

G.R. Macleod, A. Maeder, J. Muller

Editorial and Advertising Office at the EPS Secretariat.

Address: EUROPEAN PHYSICAL SOCIETY P.O. Box 69 , CH-1213 Petit-Lancy 2

Switzerland

Telephone: Geneva (22) 931130

Telex: 23455 alarm ch

Cables: europhys genève

Printed by: Pfirter frères SA $\mathrm{CH}-1213$ Petit-Lancy/Switzerland 